\title{
User Views On The Complex Accounting For Financial Instruments
}

\author{
Chyi Woan Tan, (E-mail: Rebecca.Tan@anu.edu.au), Australian National University, Australia \\ Greg Tower, (E-mail: G.Tower@cbs.curtin.edu.au), Curtin University of Technology, Australia \\ Phil Hancock, (E-mail: phancock@biz.uwa.edu.au), University of Western Australia, Australia \\ Ross Taplin, (Email: R.Taplin@murdoch.edu.au), Murdoch University, Australia
}

\begin{abstract}
This paper examines Australian and Singaporean users'views on fair value accounting for all financial instruments in financial institutions via a survey on various aspects of contention in this debate. Overall, users showed general support for fair value accounting for all financial instruments. In addition, the findings revealed that users will support fair value accounting so long as there is no perceived difference between the banking and trading books, fair values of non-traded financial instruments are reliable and volatility in earnings will not be misunderstood. It was also found that user experience increases the level of support for the proposed fair value accounting model. These results highlight actual user preferences with noticeable support for arguments from both sides of the debate (JWG and JWGBA) in this highly contentious and topical area of accounting for financial instruments.
\end{abstract}

\section{INTRODUCTION}

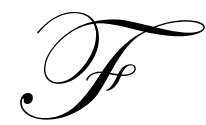

inancial instruments are an evergrowing and integral part of international business and corporations. Accounting for financial instruments has recently attracted tremendous attention due to the enormous growth of the exchange-traded derivative financial instruments market that enjoyed a turnover for financial futures and option contracts in the third quarter of 2002 of over 190 trillion US dollars, more than thirty times its level seven years ago (BIS, 2002). Such activities are concentrated in those large, financial institutions central to the world's financial system. Its sheer size and the prominence of the market players mean that the stakes in the derivatives game are very high (Hu, 1993). This rapid growth in the volume of trading of derivative financial instruments also brought about spectacular losses in organisations around the world. Barings PLC is probably the most publicised case involving huge losses associated with trading in derivatives, where the company lost in excess of US $\$ 1$ billion and brought about the demise of the company. In January 2004 in Australia the National Australia Bank reported losses from options trading of $\$ 360$ million.

These events raise important questions on the role of financial reporting and whether the current measurement and accounting for financial instruments and the information disclosed allows investors to make a proper assessment of a company's risk exposure from its derivative financial instruments. The International Accounting Standards Committee (now known as the International Accounting Standards Board) established a Joint Working Group to examine the issues associated with accounting for financial instruments. The members of the Joint Working Group of Standard Setters (JWG) included the powerful key accounting standard regulators. (US, UK, Canada, Australia, Germany, France, Japan, New Zealand, five Nordic countries and the International Accounting Standards Committee). The banking industry responded by establishing a Joint Working Group of Banking Associations (JWGBA) with representatives from the banking associations of the US, Australia, Canada, Japan and the European Union.

After a protracted period of intense deliberations, the JWG proposed the use of fair value accounting to overcome the shortcomings of current measurement practices (JWG, 1999). Under this accounting method, financial instruments are measured at the fair value of the consideration given or received. The method further proposes that all 
financial instruments be measured at fair values subsequent to initial recognition and the resultant changes in fair values taken to the Income Statement. The JWG favoured the adoption of a fair value accounting approach for all financial instruments for inclusion in the general-purpose financial statements, arguing that it provides more relevant information for investors and creditors as fair value better reflects the effects of current economic conditions and are thus better predictions of future conditions (see for example Bernard, Merton and Palepu, 1995; Barth, Landsman and Wahlen, 1995; Barth, 1994).

These views were strongly disputed by the JWGBA. The JWGBA (1999b) stated that the JWG assumed that fair value accounting is the most relevant measurement basis for all financial instruments without compelling evidence of user and preparer support. They asserted that "a full fair value system for the measurement of financial instruments in the primary financial statements of the banking industry would not be an improvement on current practice..." and "where such information is provided in the notes to the financial statements, it is not perceived by users as possessing attributes that contribute greatly to the predictive process." (JWGBA, 1999b, p.5). Furthermore, they stated that there "is no evidence that users such as investors and practicing analysts would prefer fair value accounting" (p.7) as users have not voiced concern about the current mixed model approach, which in the bankers' opinion, best reflects the underlying economic substance of banking activities. Of major concern to the JWGBA is the application of the fair value accounting method to financial instruments in the banking books. The JWGBA argues that the principal difference between the banking industry and other sectors is that a financial institution's financial instruments earn revenue from both trading and traditional banking activities, which are two entirely different areas (JWGBA, 1999b). The financial instruments from trading activities are normally measured at fair value and the JWGBA stressed that it is the appropriate method of measurement.

Banking activities consists of raising funds and investing them in assets to make a profit from the margin between the amount received on interest bearing assets and the amount paid on interest bearing liabilities. Here, the long-term customer relationship is central to this function (JWGBA, 1999a). Therefore, financial institutions are not concerned with the current value of such financial instruments, as it does not reflect the nature of the banking transactions (JWGBA, 1999a). The JWGBA (1999b) also stressed that fair values are not used in the management of the banking book because it lacks economic relevance and objectivity. Conversely, trading or non-banking activities are transactions undertaken with the objective to profit from short-term fluctuations in market prices. Here, active decisions are taken to hold or dispose of financial instruments making use of the fair value basis of measurement more appropriate, as it better represents these trading transactions and management performance.

This clash between the JWG and the JWGBA raises two crucial issues that provide the basis for this paper. Firstly, the question arises as to the appropriateness of the proposed fair value accounting method for the financial institutions' industry. In other words, does the industry agree with the views of the JWGBA or do they prefer fair value accounting for all financial instruments? The other crucial issue relates to the usefulness of the proposed fair value accounting approach to users of financial institutions' financial reports. This paper is one part of a study into these two issues and gathers evidence on Australian and Singaporean users' views regarding fair value accounting for all financial instruments.

This paper specifically examines users' preference for fair value accounting for all financial instruments and explores possible determinants of their preference. The research questions for this study are:

- $\quad$ To what extent do users in Australia and Singapore support fair value accounting for all financial instruments?

- What are determinants of users' level of support for fair value accounting for all financial instruments?

Tosen (2003, p. 13) said "When IAS 39 was released, it became clear that the standard setters had taken on a mammoth task, attempting to reconcile the views of the proponents of respectively fair value and non-fair value accounting." True to these words, the accounting for financial instruments remains a highly contentious and topical area (Pozzi, 2003; Bradbury, 2000). The fact that a total of four exposure drafts relating to various aspects of IAS 39 were released in 2004 is evidence of the continuing problems the IASB has with financial instruments. In particular the use of the fair value option has been the cause of much debate. When IAS 39 was reissued in December 2003 it 
allowed entities to elect to apply fair value accounting to all financial instruments other than those like shares in an unlisted company for which the estimate of fair value is not reliable. This option met with strong resistance particularly from some European banking regulators. For this reason the IASB issued an exposure draft in May 2004 on the fair value option proposing a more restricted use to where fair values are verifiable. However, this exposure draft did not receive widespread support and so an alternative approach only allowing the use of fair values in specific situations such as to avoid an "accounting measurement mismatch" or where an entity actively manages financial instruments on a fair value basis was inserted into IAS 39 when it was reissued in June 2005.

Research into user needs provides invaluable insights and facilitates a better understanding of the complex accounting for financial instruments in financial institutions, one of the most complex industries in terms of their accounting practices. Furthermore, this study also attempts to bridge the gap in the accounting literature in relation to user information needs. The lack of a user focus in the standard setting process is even referred to as a 'systemic problem' by Jonas and Young (1998) who urged more research into this area. Furthermore, the international controversy is based on assertions made by both JWGBA and the JWG without substantial empirical evidence on actual user information needs. Therefore, this study seeks to determine the information that sophisticated users seek in the process of making economic decisions in relation to financial instruments in financial institutions

\section{LITERATURE REVIEW}

\section{Accounting for Financial Instruments}

The accounting for and reporting of financial instruments is an area of accounting, for which existing Australian (and Singaporean) guidance has until the recent adoption of IFRSs in both countries, been inadequate. This lack of an industry standard has a significant impact on the relevance of financial reports as the use of financial instruments has increased exponentially in recent times. In the international arena, the issues related to the recognition and measurement of financial instruments are highly controversial (Alfredson, 2000).

The use of a mixed measurement model for financial instruments based on the classification of those instruments into the banking book and the trading book has been the most common approach used by financial institutions. Typically, those instruments grouped into the banking book are measured at cost while those in the trading book are fair valued. The JWG is of the opinion that the current mixed measurement model impedes comparability and allows for too much latitude by financial statements' preparers to manage earnings. IAS 39 perpetuates the use of a mixed measurement model.

Given the importance of accounting for financial instruments, accounting standard setting bodies worldwide are at differing stages in addressing this issue; some require more extensive disclosures about financial instruments, while a few have issued standards for recognition and measurement of financial instruments using a mixed measurement approach. However, no standard setter has yet proposed such a radical shift from traditional accounting concepts as advocated in the Draft Standard "Accounting for Financial Instruments and Similar Items" by the JWG with its adoption of fair value accounting for all financial instruments consistent with accepted capital markets practices and finance concepts for pricing these instruments. The draft standard proposed that virtually all financial instruments (both primary and derivative) will be measured at the fair value of the consideration given or received for it and changes in fair values to be recognised immediately in the Income Statement. Only financial instruments for which accounting standards already exist are excluded (e.g. investments in subsidiaries, associates and equity instruments). In addition, the component parts of financial instrument contracts that don't fall in the scope of the draft standard will generally be separately accounted for as freestanding financial instruments.

According to the European Central Bank (2004, p. 79), the move to fair value accounting "can be truly qualified as a paradigm shift since backward-looking accounting measures based on the concepts of prudence and reliability give way to measures based on prevailing economic values." It argues that fair value accounting may have positive consequences in terms of relevance but lacks reliability, comparability and transparency. 


\section{User Views on Fair Value Accounting}

A survey of financial analysts and other users was conducted by Sirota Consulting (an independent consultant) on behalf of the Association for Investment Management and Research (AIMR), the FASB and the Canadian Institute of Chartered Accountants (CICA). Even though the survey targeted users who are "knowledgeable and informed about fair value accounting for financial instruments", respondents were evenly divided on whether to measure financial instruments at fair value or cost. The only conclusive finding of this study is the respondents' admission of the need for more and better information regarding fair value accounting.

The American Institute of Certified Public Accountants (AICPA) (1994) conducted a comprehensive study to ascertain the information needs of users found that users do not want fair value measurement, preferring the current mixed measurement model due to the stability and consistent benchmark that it provides (JWGBA, 1999b). The study acknowledged the considerable body of research on the effects of financial information and its impact in capital markets but states that the research does not provide sufficient knowledge about users' information needs and that "high-quality research on users' needs for information has been limited" (AICPA, 1994, p. 114).

These mixed opinions between users confirm the importance of this paper. Evidence collected will provide necessary insights into actual user information needs in terms of accounting for financial instruments which can then be compared to the JWGBA (and JWG) assertions on fair value accounting for all financial instruments.

\section{SURVEY OVERVIEW}

\section{The Survey \& Demographics}

Andrews (1984) broad guidelines for questionnaire development were followed to determine users' views on fair value accounting for financial instruments. Firstly, an extensive review of related instruments was conducted and a prototype of the final survey developed. Following this, the survey was adapted to the purposes of this study in the right context and then rigorously tested for validity, relevance and optimal wording of questions through pilot testing to improve the reliability and validity of the data collected (Roberts, 1999).

A total of 379 user surveys were sent to the head of research or chief investment officers of sophisticated user organisations in Australia and Singapore. $229^{1}$ user surveys were disseminated in Australia, however, only 33 responses were received giving a low effective response rate of $16.8 \%$ (i.e. 33 out of 196). Similarly, only 32 responses were received from the 150 surveys sent to chief investment officers of sophisticated user organisations in Singapore. Fifteen surveys were returned due to errors in the address resulting in a response rate of $23.7 \%$ (i.e. 32 out of 135).

Overall, the aggregated response rate of $19.6 \%$ is relatively low $^{2}$ but consistent with the response rate of many studies in the social sciences (see Griffis, Goldsby and Cooper, 2003 and Chiu and Brennan, 1990). Due to the complexity of the topic and the response rates achieved in other studies, it is argued that the response rate is not unreasonable. Nevertheless, complete generalisation of the evidence to the financial industry should be taken cautiously. This study's strength lies in the ability to provide insights that otherwise are not available in the form of first hand evidence on actual information needs of sophisticated users in Australia and Singapore. Therefore, the evidence and results add new breadth on the perceived usefulness of fair value accounting for all financial instruments from the users' point of view. This is important given that conceptual frameworks underlying the derivation of accounting standards in many jurisdictions are based on the objective of providing decision useful information to the users of financial statements.

\footnotetext{
1 A total of 33 (a coincidence that this number is the same as the surveys completed) surveys were returned due to various reasons (people had changed jobs, the company had moved location etc.).

2 No response bias was detected where general linear models were conducted to test the effect of response time on users' experience and overall preference for fair value accounting.
} 
Seven categories of users were included in the survey namely auditors (labelled assurance and advisory), bank analyst, financial analyst, investment analyst, fund manager, industry association and an "other" grouping. These categories were then collapsed into the three dominant user groups of auditors (termed assurance and advisory), analysts (made up of financial, bank and investment analysts) and 'other' users. Table Error! Not a valid link. depicts the number of respondent from each category of user.

Table 1: Breakdown of Type of Respondent Users

\begin{tabular}{lcccc}
\hline \multicolumn{1}{c}{ Type of User } & Australia & Singapore & Total & Percent (\%) \\
\hline Assurance and Advisory & 8 & 7 & 15 & 23.0 \\
Analysts & 11 & 14 & 25 & 38.5 \\
Other & 14 & 11 & 25 & 38.5 \\
\hline Total & 33 & 32 & 65 & 100.0 \\
\hline
\end{tabular}

Respondent users represented the various groups in the survey. The 25 users from the other category included fund and trust managers and industry associations. There were 15 auditors and 25 analysts.

Users were asked to indicate their level of experience from five ranges, less than 2 years, 2 to 5 years, 6 to 10 years, 11 to 15 years and more than 15 years (see Table 2). The majority of respondents have between two to five years experience in financial reporting. About half of the respondents had more than six years experience with thirteen users having more than 15 years experience.

Table 2: The Level of Experience of User Respondents

\begin{tabular}{lcccc}
\hline & Australia & Singapore & Total & Percent $(\%)$ \\
\hline$<2$ years & 1 & 4 & 5 & 7.7 \\
2 - 5 years & 9 & 18 & 27 & 41.5 \\
6 - 10 years & 4 & 7 & 11 & 16.9 \\
11 - 15 years & 7 & 2 & 9 & 13.9 \\
$>$ 15 years & 12 & 1 & 13 & 20.0 \\
\hline Total & 33 & 32 & 65 & 100.0 \\
\hline
\end{tabular}

However, Australian users in this sample tend to be more experienced $(\mathrm{p}=0.001$, independent samples $\mathrm{T}$ test). In this instance, level of experience and country are partial surrogates for each other and any country effect may be due to an experience effect and vice versa. There is still a high degree of overlap between Singaporean and Australian users' level of experience. This surrogacy between experience and country is considered in the discussion of the regression results.

A one-way ANOVA is used to examine if average experience is significantly different for each type of user. This analysis reveals a p-value of 0.995 indicating no statistical relationship between level of experience and type of user. Therefore, there is no collinearity problem between these two independent variables.

\section{RESULTS}

This study approached users' preference for fair value accounting by examining the distinction between the trading and banking book, whether fair value accounting for all financial instruments results in decision-useful information (relevant, reliable, comparable and understandable), the earnings volatility that results from the use of fair value accounting to derive overall preference for fair value accounting for all financial instruments. This paper reports only the detailed results for the preference for fair value accounting and views on the distinction between the banking and trading books. 
The users' response were analysed as follows. Firstly, the responses of strongly oppose, oppose, neutral, support, and strongly support were replaced with the values $1,2,3,4$ and 5 respectively to quantify the strength of support for each question. Then, a one-sample t-test was used to compare the means to the midpoint position ( 3 on the 5-point scale). Significant p-values indicate that the means are significantly different from 3 (i.e. a neutral response). Non-parametric analyses based on the proportion of supporting or strongly supporting respondents out of the nonneutral respondents were also performed with one sample proportion tests. Following this, potential determinants for each theme are examined via multiple regressions by using, predominantly, the three user descriptors of country, type of user and level of experience as shown in Figure 1.

Figure 1: Diagram Of Common Possible Predictors On User Views On Key Themes Identified

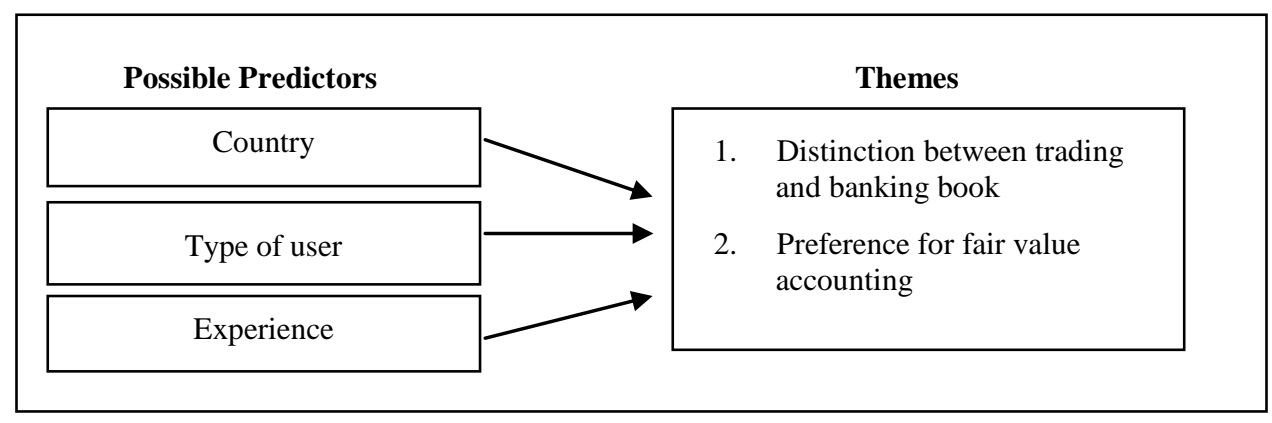

In most instances, the two-way interaction between country and the other two independent variables were also included in the linear regressions via general linear models because relationship between these independent variables may be expected to differ for the two countries.

\section{Distinction between Trading and Banking}

The main arguments put forward by the JWGBA are grounded on the purported fundamental difference between the trading and the banking book. Following this, one question in the survey attempts to examine the extent to which respondents agree (or disagree) with the assertion that trading and banking books are sufficiently different to warrant the use of different accounting measurement bases. The responses are summarised in Table 3.

Table 3: Level Of Users' Support For The Statement On The Fundamental Difference Between The Trading And Banking Books

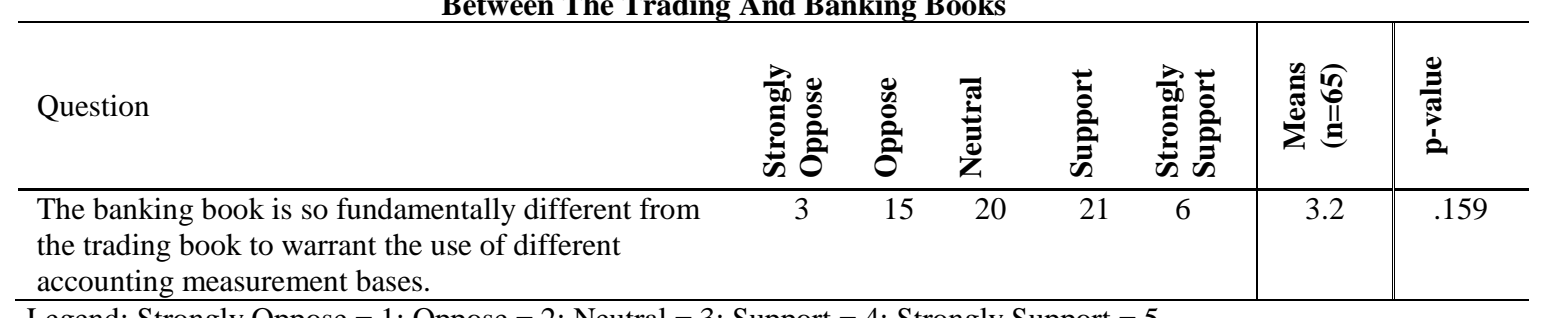

Legend: Strongly Oppose $=1 ;$ Oppose $=2 ;$ Neutral $=3 ;$ Support $=4 ;$ Strongly Support $=5$.

The JWGBA's assertion was not substantiated (mean $=3.2 ; \mathrm{p}=.159$ ) as users were neutral in relation to the purported difference between the two books. The p-value of 0.159 indicated average user response to be not significantly different from neutral (test value $=3$ ) position. However, if the 20 user respondents with neutral opinions are excluded, 27 users out of the remaining $45(60 \%)$ actually supported the use of two different accounting 
measurement bases. However, the one-sample proportion test ${ }^{3}$ indicate that $60 \%$ is not statistically different from $50 \%$ $(\mathrm{p}=0.233)$ and thus, users with opinions are divided on the issue. The JWGBA argument that the two books are distinctly different has both support (27/65) and opposition (18/65) from users. Thus this non-parametric analysis also concludes that overall support for the need for different accounting for the trading and banking books is not significantly different to neutral.

The three user descriptors of country, type of user and level of experience were then fitted in general linear models to examine if any of them are possible predictors. Country and type of user were inserted as factors while level of experience was treated as a covariate in all the models. In addition, the two-way interaction effects between country and each of the other two predictors were also included in the models to account for possible difference between countries. Scrutiny of the residual plots for each model fitted confirmed that the underlying assumptions were met. In the initial model, the three possible descriptors are included with the two-way effects between country and each of the other two predictors to account for possible country effects. Table 4 shows the significance of terms in the initial general linear. A backward elimination analysis was then performed, however this resulted in no significant variables in the final model.

Table 4: Regression Results for User Perception on the Distinction between the Trading and Banking Book

\begin{tabular}{|c|c|}
\hline 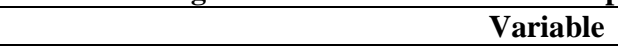 & Initial model \\
\hline Country & 0.798 \\
\hline Type of User & 0.132 \\
\hline Level of Experience & 0.135 \\
\hline Country * Type of Financial Institution & 0.268 \\
\hline Country $*$ Level of Experience & 0.657 \\
\hline Adjusted R-squared & $3.3 \%$ \\
\hline Overall significance & 0.263 \\
\hline
\end{tabular}

** Significant at the 0.05 level

*** Highly significant at the 0.01 level

None of the variables included were found to be significant predictors of users' support for the proposition that there is a fundamental different between the banking and trading books.

\section{Qualitative Characteristics and Volatility in Earnings}

Users were also asked a series of questions about their views on

- The relevance and comparability of fair value accounting,

- The reliability of fair values for traded and non-traded financial instruments, and

- $\quad$ Their perceptions on users' ability to understand the volatility in the reported earnings figure as a result of the use of fair value accounting.

The results show that users agree that fair value accounting improves the relevance of information (mean $=$ $3.5 ; \mathrm{p}=.000)$ and promotes comparability of financial statements (mean $=3.2 ; \mathrm{p}=.01$ ). The analyst group of users agreed that fair value accounting results in relevant information more than the other groups of users. Perhaps the higher level of expertise of the analysts explains this higher perception of relevance, or perhaps the time analysts spend on analysing financial statements make them appreciate the benefits of fair value accounting. Regressions on user perception on comparability, indicates that for every 1 unit increase in the level of experience, user perception of the comparability of fair value accounting financial statements across entities increases by 0.171 . As such, users with more experience tend to perceive financial statements prepared using fair value accounting to be more comparable than their less experienced counterparts. Perhaps more experienced users are more capable of understanding the

3 The one-sample proportion test is used throughout this chapter to test for difference in the proportions from the mid-way percentage $(50 \%)$. 
ramifications of fair value accounting and subsequently, are better equipped to compare different entities financial statements.

Table 5: Level of Users' Perception of the Qualitative Characteristics and Earnings Volatility of Fair Value Accounting

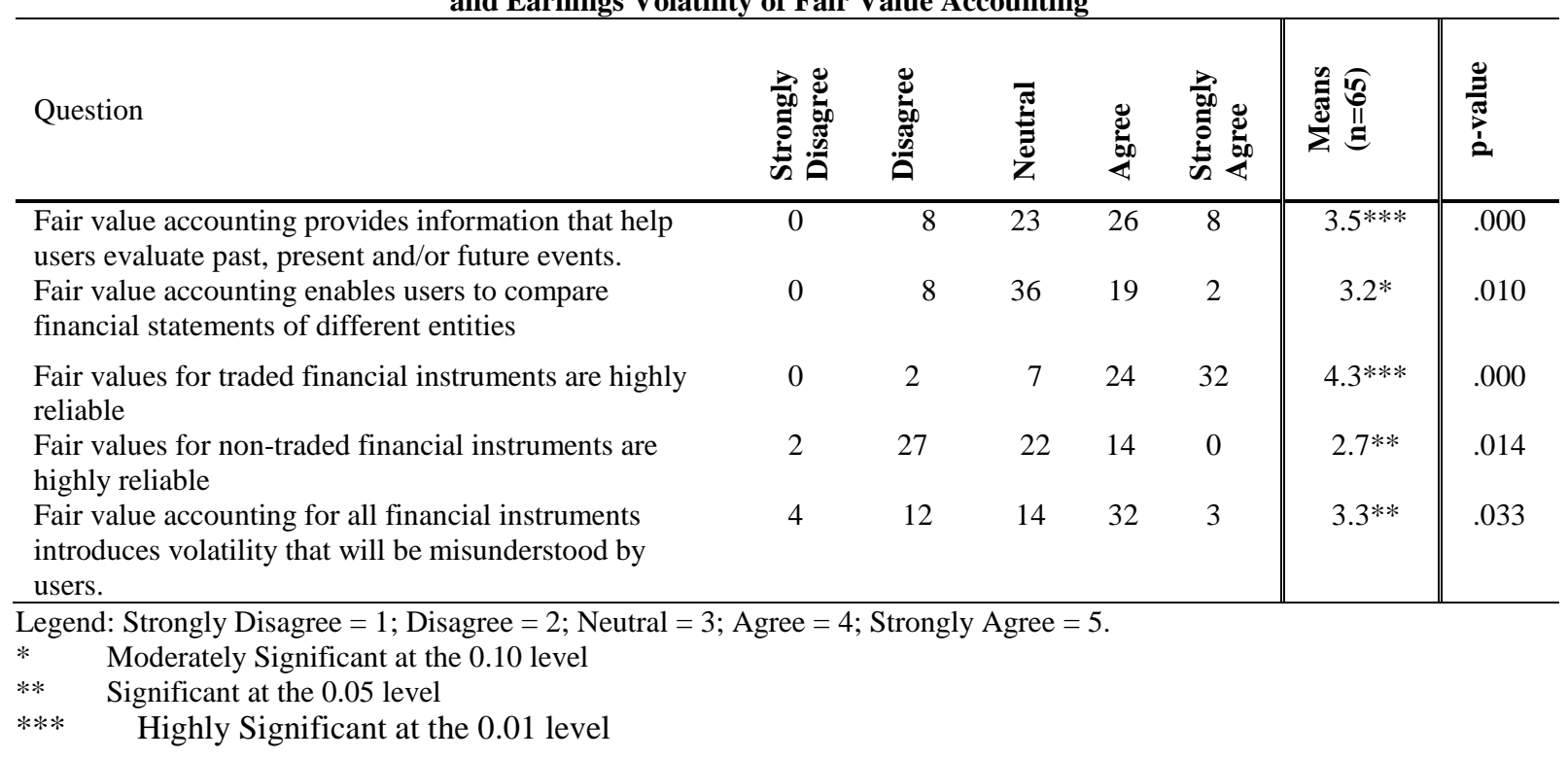

Users perceived that fair values for traded financial instruments are reliable but perceived the fair values of non-traded financial instruments to be unreliable (mean $=2.7 ; \mathrm{p}=.014$ ). They also believed that users may misunderstand the earnings volatility introduced by fair value accounting. Auditors and analysts seemed to have a higher opinion of the reliability of fair values of traded financial instruments whereas Australian auditors have a higher perception of the reliability of fair values of non-traded financial instruments as compared to the 'other' users from both countries. In relation to concerns on volatility in earnings, Australian users in the 'other' category tend around the neutral position, whereas their Singaporean counterparts are more concerned. Australian analysts expressed the strongest concerns about misrepresentations from volatility in earnings.

These qualitative characteristics are considered potential explanatory variables for support or opposition of fair value accounting in the next section.

\section{Overall Preference for Fair Value Accounting}

In the user survey, fair value accounting was specifically defined as the measurement of all financial instruments at fair value and the recognition of changes in fair value as revenues or expenses in the Income Statement in the period in which they arise. Sophisticated users were asked the extent they support (or oppose) fair value accounting for all financial instruments. See Table 5 for the responses.

The average response of users was a statistically significant 3.5 score indicating support for comprehensive fair value accounting. In addition, when the 12 users with neutral opinions are excluded, $68 \%(\mathrm{p}=0.013$ in onesample proportion test) of users support the use of fair value accounting for all financial instruments. At first glance, respondent users are supportive of fair value accounting for all financial instruments. However, user preference is still varied as evidenced by the 17 users who oppose this approach and the 12 users who are neutral on the matter. 
Table 6: Users' Support for Fair Value Accounting for All Financial Instruments

Question
$\begin{aligned} & \text { Do you support the use of fair value accounting for } \\ & \text { all financial instruments? }\end{aligned}$

The three variables of country, type of user and level of experience together with the two-way interactions between country and the other two variables were included in the initial general linear regression model to check for predictors of user preference for fair value accounting. However, users' perception on the fundamental difference between the trading and banking book, their opinion on the qualitative characteristics possessed by fair value accounting as well as the impact of earnings volatility on users' decisions may affect their overall preference for fair value accounting. Therefore, in addition to the aforementioned variables, users' responses for the questions related to trading versus banking book distinction, the qualitative characteristics and problems with volatility of reported earnings are also included as covariates in the initial general linear model fitted. A backward elimination process was then applied to this initial model, as before, and the significance of terms in the resulting final model are also displayed in Table 6. Again, residual plots for each model fitted were checked and there was no violation of underlying assumptions.

Table 7: Regression Results for User Preference for Fair Value Accounting

\begin{tabular}{lcc}
\hline \multicolumn{1}{c}{ Variable } & Initial model & Final model \\
\hline Country & 0.198 & 0.843 \\
Type of Financial Institution & $0.073^{*}$ & $0.006^{* * *}$ \\
Level of Experience & 0.921 & \\
Country * Type of User & 0.302 & $0.001^{* * *}$ \\
Country * Level of Experience & $0.009 * * *$ & \\
No distinction between trading and banking book & 0.139 & \\
Support for Relevance & 0.899 & 0.666 \\
Support for Comparability & $0.068^{*}$ & $0.017 * * *$ \\
Support for Reliability of Traded financial instruments & $0.002^{* * *}$ & $0.000^{* * *}$ \\
Support for Reliability of Non-traded financial instruments & $51.4 \%$ & $54.1 \%$ \\
Volatility will not be misunderstood & $0.000^{* * *}$ & $0.000^{* * *}$ \\
\hline Adjusted R-squared & & \\
\hline Overall significance & & \\
\hline
\end{tabular}

* Moderately significant at the 0.10 level. *** Highly significant at the 0.01 level

Therefore, according to the final model: (1) the level of experience, (2) no distinction between the trading and banking book, (3) reliability of non-traded financial instruments, and (4) earnings volatility will not be misunderstood influence users' preference for fair value accounting. Note that while the level of experience seems to be a partial surrogate for country it is consistently a more significant variable than country in the regressions. These significant relationships are described in the following sections.

\section{Level of Experience}

According to the regression coefficient of 0.226 , for every 1 unit increase in the level of experience, user support for fair value accounting increases by 0.226 . Therefore, users with more experience tend to support fair value accounting for all financial instruments more than their less experienced counterparts. The complexity of fair value accounting and financial instruments in general could be the reason for this. Perhaps more experienced users are more familiar with the complexity and thus more comfortable with the change to fair value accounting for all financial instruments. 


\section{No Distinction between Banking and Trading Books}

Users who perceive that the trading book is not fundamentally different from the banking book tend to prefer fair value accounting as compared to their counterparts. The regression coefficient for this variable is 0.351, indicating that for every 1-unit increase in the perception of no difference between the two books, user average support for fair value accounting increases by 0.351 . It seems that so long as these two books are seen to be fundamentally different, there will be continued opposition to fair value accounting for all financial instruments.

\section{Reliability of Fair Values of Non-traded Financial Instruments}

Respondent users that perceive fair values of non-traded financial instruments to be reliable tend to support fair value accounting for all financial instruments. A regression coefficient of 0.341 shows that for every 1 -unit increase in the perception on the reliability of fair values for non-traded financial instruments, the average support for fair value accounting increases by 0.341. This lends weight to the JWGBA assertions that the use of fair values will suffer from problems with obtaining reliable fair values for financial instruments that have no active markets. Therefore, it seems that users support the use of fair value accounting for all financial instruments if methodologies for calculating reliable fair values for non-traded financial instruments can be established.

\section{Earnings Volatility will not be Misunderstood}

Users with the view that the volatility in reported earnings resulting from the use of fair value accounting for all financial instruments will not be misunderstood by users favour the use of fair value accounting. A regression coefficient of 0.408 shows that for every 1-unit increase in the perception that the resultant earnings volatility will not be misunderstood, average user support for fair value accounting increases by 0.408 . This gives credibility to the JWGBA assertions. It seems that users concerned with the earnings volatility introduced by fair value accounting will only support its use if they can be convinced that such earnings volatility will not be misunderstand by users.

\section{IMPLICATIONS AND CONCLUSION}

The motivation for the paper is derived from the conflict that exists between the JWG and the JWGBA. The aim of this study is to gather evidence as to the views of Australian and Singaporean users in relation to fair value accounting.

The user responses showed a trend of general support for fair value accounting for all financial instruments. The main obstacle to the support for fair value accounting is the users' perception that fair values for non-traded financial instruments are unreliable. In addition, the findings revealed that users will support fair value accounting so long as there is no perceived difference between the banking and trading books, reliable fair values of non-traded financial instruments can be established and earnings volatility will not be misunderstood by users. It was also found that user experience increases the level of support for the fair value accounting method indicating that the accounting for financial instruments remains a complex issue where experience increases users' comprehension of all the issues. This evidence indicates support for the proposed fair value accounting approach from the users' point of view giving credence to the JWG assertions. There were also instances where users agree with the JWGBA, for example, that fair value accounting may introduce confusing earnings volatility and lacks reliability with some financial instruments.

There were instances where Australian users tended to be more supportive of the fair value accounting method. This support may be explained by the active accounting standard process and international accounting influence in Australia as compared to the rather subdued accounting environment in Singapore (Soewarso, Tower, Hancock and Taplin, 2003). The Australian business profession's active involvement in the standard setting process both locally and internationally may have led to a better understanding of the workings and the ramifications of using fair value accounting for all financial instruments. 
The evidence shows that user respondents would use fair value accounting information if it was provided. Results showed general support for fair value accounting for all financial instruments although there were varied responses for each theme discussed. This further stresses the need for more research into this complex area of accounting for financial instruments. Although users generally perceive fair value accounting for all financial instruments results in information useful for decision making purposes as per the IASB Framework, there is still considerable disagreement.

These findings highlight the variation in users' perceptions on this issue and confirm that the resolution to the measurement of financial instruments will be difficult for the standard setters. The IASB's recent experience with the "fair value option" referred to earlier in this paper, is an indication of the enormity of the task. The results of this paper suggest the IASB should focus on establishing methodologies for the reliable measurement of fair values for all financial instruments and obtaining compelling evidence that earnings volatility will not be widely misunderstood by users if they are inclined towards the fair value accounting method for all financial instruments.

\section{ACKNOWLEDGMENTS}

The authors would like to express their appreciation to participants of the 2005 European Applied Business Research Conference in Athens, Greece, for their critical comments and advice on earlier drafts.

\section{REFERENCES}

1. AICPA, (1994) Improving business reporting - A customer focus: Meeting the information needs of investors and creditors, American Institute of Certified Public Accountants, New York, USA.

2. Alfredson, K. (2000) AASB Media Release: AASB Invites Comment on Proposals on the Measurement and Recognition of Financial Instruments, Australian Accounting Standards Board.

3. Andrews, F. M. (1984) Construct validity and error components of survey method, Public Opinion Quarterly, 11, 409-442.

4. Bank for International Settlements (BIS) (2002) International Banking and Financial Market Developments, Monetary and Economic Department, Basel, Switzerland.

5. Barth, M. E. (1994) Fair value accounting: Evidence from investment securities and the market valuation of banks, The Accounting Review, 69, 1-25.

6. Barth, M. E., Landsman, W. R. and Wahlen, J. M. (1995) Fair value accounting: Effects on banks' earning volatility, regulatory capital and value of contractual cash flows, Journal of Banking and Finance, 19, 557604.

7. $\quad$ Bernard, V. L., Merton, R. C. and Palepu, K. G. (1995) Mark-to-market accounting for banks and thrifts: Lesson from the Danish Experience, Journal of Accounting Research, 33, 1-31.

8. Bradbury, M. E. (2000) Issues in the drive to measure liabilities at fair value, Australian Accounting Review, $10,19-25$.

9. Chiu, I., and Brennan, M. (1990) The effectiveness of some techniques for improving mail survey response rates: A meta-analysis, Marketing Bulletin, 1, 13-18.

10. European Central Bank (ECB) (2004) The impact of fair value accounting on the European banking sector A financial stability perspective, ECB Monthly Bulletin, February 2004, 69-81.

11. Fargher, N. (2001) Management perceptions of fair-value accounting for all financial instruments, Australian Accounting Review, 11, 62-73.

12. Griffis, S. E., Goldsby, T. J., and Cooper, M. (2003) Web-based and mail surveys: A comparison or response, data, and cost, Journal of Business Logistics, 24, 237-258.

13. Hu, H. T. C. (1993) Misunderstood derivatives: The cause of informational failure and the promise of regulatory incrementalism, Yale Law Journal, 102, 1457-1513.

14. International Accounting Standards Committee (2003) International Accounting Standards 2003, International Accounting Standards Committee, London, UK.

15. Joint Working Group of Banking Associations (1999a) Accounting for Financial Instruments for Banks.

16. Joint Working Group of Banking Associations (1999b) Financial Instruments: Issues Relating to Banks Comments on the JWG Paper. 
17. Joint Working Group of Standard Setters (JWG) (1999) Financial Instruments: Issues Relating to Banks.

18. Jonas, G. J., and Young, S. J. (1998) Bridging the gap: Who can bring user focus to business reporting, Accounting Horizons, 12, 154-159.

19. Pozzi, C. (2003) Changes afoot, CA Charter, 74, 54-55.

20. Roberts, E. S. (1999) In defense of the survey method: An illustration from a study of user information satisfaction, Accounting and Finance, 39, 53-77.

21. Soewarso, E., Tower, G., Hancock, P., and Taplin, R. (2003) Comparative Study of De Jure and De Facto Disclosure between Australia and Singapore, Asian Review of Accounting, 11, 18-47.

22. Tosen, G. (2003) The tainting dilemma, Accountancy SA, June, 13.

\section{NOTES}

